
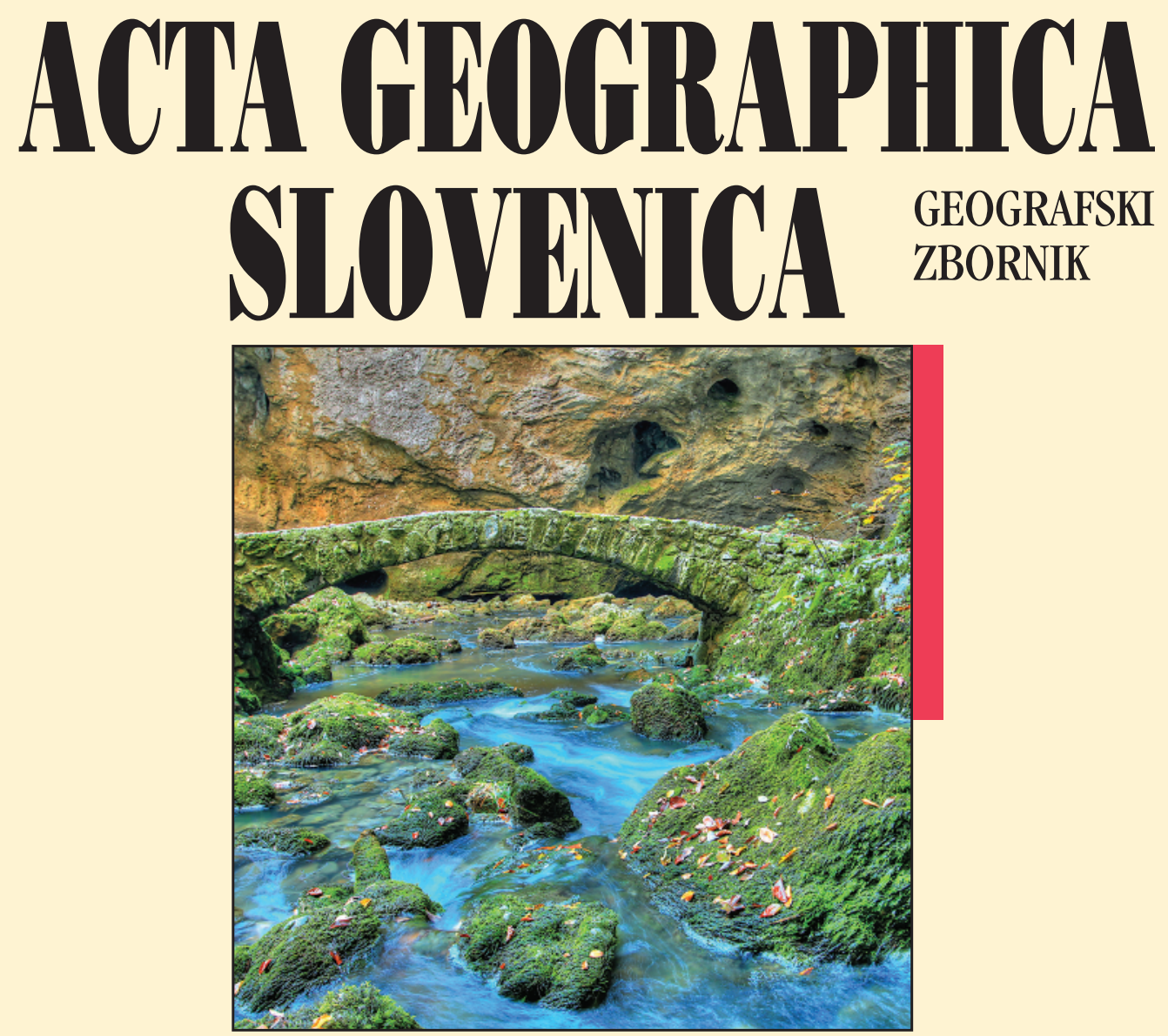


\section{ACTA GEOGRAPHICA SLOVENICA GEOGRAFSKI ZBORNIK \\ 59-1 • 2019}

\section{Contents}

Maja KOCJANČIČ, Tomislav POPIT, Timotej VERBOVŠEK

Gravitational sliding of the carbonate megablocks in the Vipava Valley, SW Slovenia

Małgorzata KIJOWSKA-STRUGAŁA, Anna BUCAŁA-HRABIA

Flood types in a mountain catchment: the Ochotnica River, Poland

Irena MOCANU, Bianca MITRICĂ, Mihaela PERSU

Socio-economic impact of photovoltaic park: The Giurgiu county rural area, Romania

Andrej GOSAR

The size of the area affected by earthquake induced rockfalls: Comparison of the 1998 Krn Mountains (NW Slovenia) earthquake $\left(M_{w} 5.6\right)$ with worldwide data

Matej GABROVEC, Peter KUMER

Land-use changes in Slovenia from the Franciscean Cadaster until today

Mojca FOŠKI

Using the parcel shape index to determine arable land division types

Mateja FERK, Matej LIPAR, Andrej ŠMUC, Russell N. DRYSDALE, Jian ZHAO

Chronology of heterogeneous deposits in the side entrance of Postojna Cave, Slovenia

\section{Special issue - Green creative environments}

Jani KOZINA, Saša POLJAK ISTENIČ, Blaž KOMAC

Green creative environments: Contribution to sustainable urban

and regional development

Saša POLJAK ISTENIČ

Participatory urbanism: creative interventions for sustainable development

Jani KOZINA, Nick CLIFTON

City-region or urban-rural framework: what matters more in understanding

the residential location of the creative class?

Matjaž URŠIČ, Kazushi TAMANO

The importance of green amenities for small creative actors in Tokyo:

Comparing natural and sociocultural spatial attraction characteristics

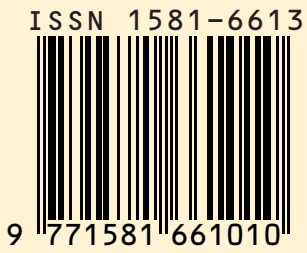




\section{ACTA GEOGRAPHICA SLOVENICA}

$59-1$

2019

ISSN: 1581-6613

COBISS: 124775936

UDC/UDK: 91

(C) 2019, ZRC SAZU, Geografski inštitut Antona Melika

International editorial board/mednarodni uredniški odbor: David Bole (Slovenia), Michael Bründl (Switzerland), Rok Ciglič (Slovenia), Matej Gabrovec (Slovenia), Matjaž Geršič (Slovenia), Peter Jordan (Austria), Drago Kladnik (Slovenia), Blaž Komac (Slovenia), Andrej Kranjc (Slovenia), Dénes Lóczy (Hungary), Simon McCharty (United Kingdom), Slobodan Marković (Serbia), Janez Nared (Slovenia), Drago Perko (Slovenia), Marjan Ravbar (Slovenia), Nika Razpotnik Visković (Slovenia), Aleš Smrekar (Slovenia), Annett Steinführer (Germany), Mimi Urbanc (Slovenia), Matija Zorn (Slovenia)

Editor-in-Chief/glavni urednik: Blaž Komac; blaz@zrc-sazu.si

Executive editor/odgovorni urednik: Drago Perko; drago@zrc-sazu.si

Chief editor for physical geography/glavni urednik za fizično geografijo: Matija Zorn; matija.zorn@zrc-sazu.si Chief editor for human geography/glavna urednica za humano geografijo: Mimi Urbanc; mimi@zrc-sazu.si

Chief editor for regional geography/glavni urednik za regionalno geografijo: Drago Kladnik; drago.kladnik@zrc-sazu.si

Chief editor for spatial planning/glavni urednik za regionalno planiranje: Janez Nared; janez.nared@zrc-sazu.si

Chief editor for rural geography/glavna urednica za geografijo podeželja: Nika Razpotnik Visković; nika.razpotnik@zrc-sazu.si Chief editor for urban geography/glavni urednik za urbano geografijo: David Bole; david.bole@zrc-sazu.si

Chief editor for geographic information systems/glavni urednik za geografske informacijske sisteme: Rok Ciglič; rok.ciglic@zrc-sazu.si

Chief editor for environmental protection/glavni urednik za varstvo okolja: Aleš Smrekar; ales.smrekar@zrc-sazu.si

Editorial assistant/uredniški pomočnik: Matjaž Geršič; matjaz.gersic@zrc-sazu.si

Issued by/izdajatelj: Geografski inštitut Antona Melika ZRC SAZU

Published by/založnik: Založba ZRC

Co-published by/sozaložnik: Slovenska akademija znanosti in umetnosti

Address/Naslov: Geografski inštitut Antona Melika ZRC SAZU, Gosposka ulica 13, SI - 1000 Ljubljana, Slovenija

The papers are available on-line/prispevki so dostopni na medmrežju: http://ags.zrc-sazu.si (ISSN: 1581-8314)

Ordering/naročanje: Založba ZRC, Novi trg 2, p. p. 306, SI - 1001 Ljubljana, Slovenija; zalozba@zrc-sazu.si

Annual subscription/letna naročnina: $20 €$ for individuals/za posameznike, $28 €$ for institutions/za ustanove.

Single issue/cena posamezne številke: $12,50 €$ for individuals/za posameznike, $16 €$ for institutions/za ustanove.

Cartography/kartografija: Geografski inštitut Antona Melika ZRC SAZU

Translations/prevodi: DEKS, d. o. o.

DTP/prelom: SYNCOMP, d. o. o.

Printed by/tiskarna: Tiskarna Present, d. o. o.

Print run/naklada: 350 copies/izvodov

The journal is subsidized by the Slovenian Research Agency and is issued in the framework of the Geography of Slovenia core research programme (P6-0101)/revija izhaja s podporo Javne agencije za raziskovalno dejavnost Republike Slovenije in nastaja v okviru raziskovalnega programa Geografija Slovenije (P6-0101).

The journal is indexed also in/revija je vključena tudi v: SCIE - Science Citation Index Expanded, Scopus, JCR - Journal Citation Report/Science Edition, ERIH PLUS, GEOBASE Journals, Current geographical publications, EBSCOhost, Geoscience e-Journals, Georef, FRANCIS, SJR (SCImago Journal \& Country Rank), OCLC WorldCat, Google scholar, and CrossRef

Oblikovanje/Design by: Matjaž Vipotnik.

Front cover photography: Stone bridge over the Rak River on the outskirts of the Rakov Škocjan polje, which is otherwise known for its beautiful natural bridges (photograph: Matej Lipar).

Fotografija na naslovnici: Kamniti most čez reko Rak na obrobju kraškega polja Rakov Škocjan, ki je sicer bolj znano po čudovitih naravnih mostovih (fotografija: Matej Lipar). 


\section{CITY-REGION OR URBAN-RURAL FRAMEWORK: WHAT MATTERS MORE IN UNDERSTANDING THE RESIDENTIAL LOCATION OF THE CREATIVE CLASS?}

Jani Kozina, Nick Clifton

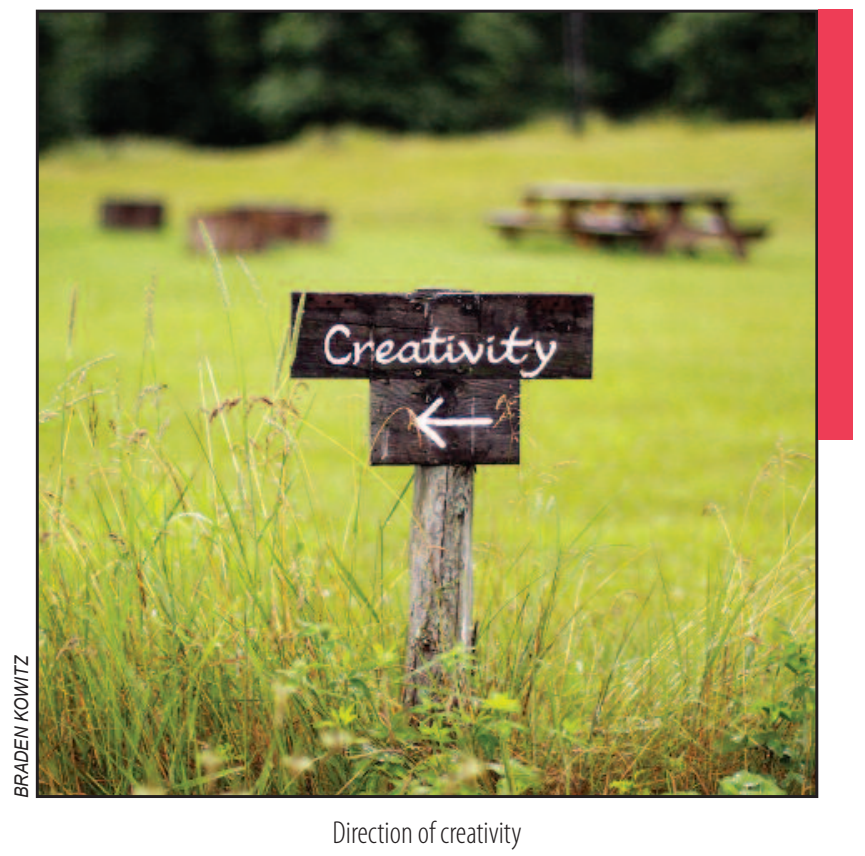




\title{
City-region or urban-rural framework: what matters more in understanding the residential location of the creative class?
}

\begin{abstract}
This paper addresses the key question as to what matters more in understanding the residential location of the creative class in Slovenia: the city-region or the urban-rural framework? Our analysis shows that differences in residential concentrations of the creative class vary more within city-regions (on an urban-rural framework) than between city-regions. Moreover, the creative class is moving out of densely populated urban areas to more sparsely populated suburban / rural areas within all city-regions. There also are significant differences between more developed western Slovenia (denser settlement structures) and less developed eastern Slovenia (sparser settlement structures). We conclude that new models of living promote dispersion.
\end{abstract}

KEY WORDS: creative class, knowledge economy, regionalisation, urbanisation, suburbanisation, dispersion, residential preferences, economic geography

\section{Delitev na regije ali mesto in podeželje: kaj je pomembneje za razumevanje razporeditve ustvarjalnih ljudi po kraju bivanja?}

POVZETEK: Namen prispevka je odgovoriti na vprašanje, kaj je pomembneje za razumevanje razporeditve ustvarjalnih ljudi po kraju bivanja v Sloveniji: delitev na regije ali mesto in podeželje? Analize kažejo, da se razlike v koncentraciji ustvarjalnih ljudi po kraju bivanja bolj razlikujejo znotraj regij (med mesti in podeželjem) kot med regijami. Poleg tega se ustvarjalni ljudje pomikajo iz gosteje poseljenih mestnih območij v redkeje naseljena primestna / podeželska območja v vseh regijah. Obstajajo tudi velike razlike med bolj razvito zahodno Slovenijo (gostejša poselitev) in manj razvito vzhodno Slovenijo (bolj razpršena poselitev). Sklepamo, da novi modeli življenja spodbujajo razpršenost.

KLJUČNE BESEDE: ustvarjalni ljudje, ekonomija znanja, regionalizacija, urbanizacija, suburbanizacija, disperzija, bivanjske preference, ekonomska geografija

\section{Jani Kozina}

Research Centre of the Slovenian Academy of Sciences and Arts, Anton Melik Geographical Institute jani.kozina@zrc-sazu.si

\section{Nick Clifton}

Cardiff Metropolitan University, Cardiff School of Management nclifton@cardiffmet.ac.uk

The article was submitted for publication on May $11^{\text {th }}, 2017$.

Uredništvo je prejelo prispevek 11. maja 2017. 


\section{Introduction}

The key question addressed by this paper is what matters more in understanding the residential location of the creative class: city-region or urban-rural framework? A detailed investigation aims to get a deeper insight into residential characteristics of the creative class within city-regions in Slovenia from the perspective of their level of urbanisation. By doing this, we seek to set the frame for studying intraregional relations in attracting, retaining or releasing the creative-knowledge potential in specific territorial contexts. The hypothesis is that differences in residential concentration of the creative class between urban and rural areas are bigger than between city-regions. In this way the paper intends to add weight to an urban-rural framework for studying and planning creative-knowledge city-regions.

In addition, much of the theoretical work on city-regions is firmly located in the urban experience of North America and Western Europe (Roy 2009), so the contribution of this paper may also be understood as an extension of the research agenda to other European territories and as a mode to reconfigure the theoretical heartland of urban, rural and regional analysis by presenting new evidences from Slovenia.

Although we can trace the origins of the city-region paradigm back to the 1909 Plan of Chicago (Geddes 1915; McKenzie 1933; Dickinson 1947), the concept of the city-region does still not enjoy a common definition in present times (Parr 2005; Harrison 2007; Davoudi 2008; Rodríguez-Pose 2008). However, the need for a spatial definition of the city-region is imperative when concern is with such matters as the analysis of structural change, the design, implementation, and evaluation of policy, spatial and temporal comparisons (Parr 2008). Investigating city-region's structure and nature is an ongoing and relevant task since city-regions form a network of supranational economic systems (Scott and Storper 2003; Jonas and Ward 2007; Harrison and Heley 2015). In global competition, those city-regions that are able to capture eminent positions and to gain economic advantages can create favourable conditions for both their cities and wider regions (Egedy, Kovács and Kondor 2016). To this end we need a better insight about the relationship of a city-region's material-physical structure to its economic performance (Storper 2013).

The minimum common denominator of virtually all definitions of a city-region is the presence of a core city linked by functional ties to a hinterland (Rodríguez-Pose 2008). The core city possesses some specified set of functions or economic activities; thus it may account for a substantial proportion of the population of the city-region (sometimes in excess of 50\%) and is invariably the dominant urban centre. The hinterland contains a rural population and (in advanced economies) a much larger urban population, arranged within a hierarchy of centres, the core city representing the highest level of the hierarchy (Parr 2005; 2008). As exposed by Davoudi (2008), multifaceted definitions of a city-region share two common features. Firstly, they portray an urban-centric conception of the city-region that puts emphasis on the core city, sometimes at the expense of neglecting the region and rural areas. Secondly, they represent an economically driven approach to city-region definition in which the dominant economic flows determine the extent of the cityregion.

Despite the variations among nations of the developed world, it was generally the case that well into the $20^{\text {th }}$ century there was a continuing trend toward concentration of the spatial structure, with the core city increasing its share of the city-region's population, employment and income. This was prompted in no small degree by the rise of manufacturing that, because of the importance of agglomeration economies, favoured development in the core city. In more recent decades, however, the spatial structure of city-regions in the developed world had undergone something of a transformation and was evolving differently. Due to technical change, developments in transport and communication, changing patterns of work, mobility and lifestyle in rural areas, steadily rising levels of income, and negative externalities of the core city, population (first) and employment (later) gradually began to shift to the hinterland, the overall outcome representing a trend toward deconcentration within the city-region (Parr 2005).

Thus the city-region is not a static construct (Parr 2008) and as Harrison and Heley (2015) emphasize there is a need for taking into consideration the hitherto neglected temporal dimension into sharper focus. The recent trends of spatial organization of city-regions clearly imply dispersion - territorial aspect and diversification - sectorial aspect. However, in recent times the focus is on the creative-knowledge economy (Bontje, Musterd and Pelzer 2011) that is sharply different from the past. Thus it is similarly expected to produce its own space through reshaping the industrial city and region to a new form that would suit the new conditions for economic production and their associated social habits and institutions (Madanipour 2011). 


\subsection{Urban-rural framework: an underutilized aspect of a city-region concept}

When discussing the structure and nature of city-regions the accent is clearly on urban areas or superagglomerations and their development (Scott and Storper 2003). This is problematic from two perspectives. First, it seems that the prevailing literature on city-regionalism is more interested in comparisons between than within city-regions, typically emphasising narrow definitions of competitiveness at the expense of more holistic considerations of internal cohesion and resilience (as per Bristow 2010). Since city-regions may contain greater variations in economic characteristics within them (e.g., urban vs. rural) than between them, comparisons between city-regions can potentially be misleading (Bakhshi et al. 2015). Second, a debate remains concerning the extent to which rural localities are incorporated within city-region boundaries (Healey 2009) and development policies (Harrison and Heley 2015). Subsequently, there is the view that city-region approaches to economic development are having a detrimental impact on the competitiveness of rural areas (Gülümser, Baycan-Levent and Nijkamp 2010; Huggins and Clifton 2011) and can reinforce rather than resolve the problems of uneven development and socio-spatial inequalities (Etherington and Jones 2009).

The first ideas of combining urban and rural aspects in planning dates at least back to Ebenezer Howard and his book Garden Cities of Tomorrow (first published in 1898 under the title To-morrow, and republished under its better-known title in 1902) in which he argued that both cities and countryside had an indissoluble mixture of advantages and disadvantages (Hall and Tewdwr-Jones 2011). However, it was only in the 1960s when the spatial linkages between urban and rural areas became a common concern that urban analysts turned their attention away from the city and towards the city-region (Davoudi and Stead 2002). Proponents on the one hand argue that the city-region model provides a potential link between urban and rural areas in a way that the competitive and complementary aspects of urban-rural relations become more transparent, and this is particularly so for labour and housing markets, as well as for shopping and leisure patterns (Parr 2005; 2008; Davoudi 2008). Conceptualized as such, city-regions are increasingly regarded as the appropriate sub-regional scale for the implementation of development policies (Rodríguez-Pose 2008).

However, opponents on the other hand argue that there is a limit to how far city-regionalism - as currently constructed - can represent the interests of the population at large (Harrison and Heley 2015). As stated by Woods (2009), it carries the risk of addressing rural localities solely in terms of their relation to the urban, of disregarding any sense of an overarching, interregional rural condition, and of marginalizing rural concerns within structures dominated economically and demographically by cities. Furthermore, it establishes and reinforces out-of-date notions of geographical centrality and hierarchies, and it actively marginalises places, consigning them to the periphery, dividing and polarising (Ward 2006). This can also increase differences in values and political orientation between urban and rural dwellers (Tiran 2011; 2015). Pemberton and Shaw (2012) added that whilst significant attention has been placed on the impact of new sub-regional governance arrangements on urban areas, there has been little consideration of the nature and effectiveness of such arrangements on rural areas.

Because economic activities are territorialized (Storper 1997), there is a need for more integrated, locally specific, place development agendas (Healey 2009; Bontje et al. 2011). Nevertheless, there remains a noticeable silence in city-region debates concerning how rural spaces are conceptualised, governed and represented (Harrison and Heley 2015), despite the fact that they are important spaces that cannot be ignored (Pemberton and Shaw 2012). Research that explicitly interrogates the role of rural areas within a city-region framework is therefore important and welcome (Woods 2009). However, whilst there is considerable literature on both rural and urban development issues, there is much less concerning the linkages between them (Davoudi and Stead 2002).

\subsection{Creative-knowledge economy and a city-region}

The literature on the emerging creative-knowledge economy often suggests that city-regions are the focal points of this economy. Hence, it is hard to imagine an alternative economic growth path for city-regions in advanced capitalist countries that would replace the current focus on creativity, knowledge and innovation (Bontje, Musterd and Pelzer 2011).

However, to understand the geography of the creativity, and to formulate supportive policies for both urban and rural areas, it is necessary to analyse it at a sub-regional or even neighbourhood level (Clifton 2008). 
Analysis at a high degree of spatial resolution allows concentrations of a particular activity to be more accurately identified; to this end, in this paper we employ an occupational, residence-based operationalisation of creative activity - aka the creative class (Clifton 2008; Boschma and Fritsch 2009; see the section below for a full discussion of this methodology). Concentrations of such activity may also occur at small spatial scales, so it is desirable to analyse the data at the smallest possible scale for which official statistics are available (Bakhshi et al. 2015).

Nevertheless, most of the previous mappings concerned with the creative economy addressed regional or metropolitan scale (e.g. Florida 2002; Marlet and van Woerkens 2007; Clifton 2008; Rutten and Gelissen 2008; Boschma and Fritsch 2009; Andersen et al. 2010). They revealed that creative-knowledge workers are more intensively located in predominantly urban regions. There have been rare attempts to unveil intraregional disparities by simultaneously examining urban and rural areas, despite sub-regional scales of working increasingly being promoted as means of securing greater spatial equity and economic competitiveness (Harrison and Heley 2015). The reasons for this can be ascribed to a historical focus on the benefits of urban areas on the account of their creative capacity and the limited availability of secondary data on rural areas, plus the difficulty in collecting accurate primary data and the lack of comparable data (Gülümser, Baycan-Levent and Nijkamp 2010). However, as investigated in selected European metropolitan areas of Amsterdam, Birmingham, Helsinki, Poznan, Riga, and Toulouse, creative-knowledge workers are concentrated not only in traditional core cities, but also in new centres on the city edges and beyond. More specifically, city centres may mainly attract the »creative core « (scientists and engineers, architects and designers, academics and teaching professionals), while city edges and beyond may be more attractive for $» c r e a t i v e$ professionals « (associated professional and technical occupations of the creative core, managers, financial and legal professionals) (Bontje and Kepsu 2013).

Recent theories on regional creativity often focus on urban areas without taking into account rural localities. In addition, the application of such analyses to rural areas may lead to misrepresentation or misunderstanding of rural creative capacity. Thus, there is a need to combine the current knowledge on innovation and rural areas in order to conduct more effective research (and policies) for achieving sustainable rural development (Gülümser, Baycan-Levent and Nijkamp 2010). Although conditions for creating or stimulating creative-knowledge economies in the context of a global world certainly depend on urban history (Pareja-Eastaway and Pradel i Miquel 2015), they also play a significant role in the development of rural areas (McGranahan and Wojan 2007). As suggested by Madanipour (2011), the creative workers can be found and developed not only in elite centres, but also in the peripheries, smaller cities and towns, and in the »less-favoured « parts of larger cities. However, little, if any, locality-specific qualitative or quantitative research has been undertaken to assess the residential preferences of creative-knowledge workers in a regional context (Verdich 2010).

\section{Methods}

The aim of this paper is to measure the (re)distribution of the creative class across and within the cityregions of Slovenia in the period 2000-2011. To this end, it employs microdata from the Statistical Register of Employment by the Statistical Office of the Republic of Slovenia. The fine-grained data allows distinction between different types of urbanisation as residential places of the creative class.

The investigated city-regions are functional regions. Their boundaries correspond to a large extent to travel-to work areas (see Bole 2004). In size they are similar to NUTS 3 regions. The latter are twelve, whereas we distinguish between eight city-regions in Slovenia. Such regionalization is often mentioned as one of the most appropriate as the second level of local self-government (Ravbar 1997; Plut 1999; Kozina 2010) but is officially not established yet. The largest city-region is the Osrednja Slovenija (core city: Ljubljana), with a population of almost a third of the country's population ( $2 \mathrm{~m}$ in total). The Podravska (core city: Maribor) and Savinjsko-Koroška (core city: Celje) city-regions represent half of its size, while other city-regions are even smaller. Central and western city-regions are more successful than the eastern ones, which lag behind (Ravbar 2009). The differences are greater with regard to economic issues and smaller with regard to social and environmental issues (Vintar Mally 2018).

The urban-rural typology used in this paper is based on the work of Ravbar (1997). The data were later revised by Krevs et al. (2005) and the number of types were simplified and diminished from seven 
to four. The types were estimated on the basis of a set of sociogeographic, physiognomic, structural, and functional criteria. The urban-rural typology consists of four residential types as follows:

- urban settlements (degree of urbanisation =100\%);

- suburbanised settlements $(75 \%<$ degree of urbanisation $<100 \%)$;

- urbanised rural settlements $(55 \%<$ degree of urbanisation $<75 \%)$;

- rural settlements (degree of urbanisation $<55 \%$ ).

Altogether, there are around 6,000 settlements in Slovenia. Overall, 43\% of the population reside in "urban areas«, $22 \%$ in »suburbanised areas«, $15 \%$ in »urbanised rural areas «, and $20 \%$ in »rural areas«.

The definition of the creative class is adopted from the works of Florida $(2002 ; 2005 ; 2008)$, which separates the creative class from others based on their occupation, while additionally differentiating between members of the creative core, creative professionals, and bohemians. The fundamental idea is that of the secondary data that is available, occupation is the best proxy of how an individual uses knowledge and creativity in the work. In the technical sense, we used the example of the Technology, Talent and Tolerance in European Cities: A Comparative Analysis European research project's methodology (e.g. Fritsch and Stützer 2007; Marlet and van Woerkens 2007; Clifton 2008; Boschma and Fritsch 2009; Andersen et al. 2010) and the Slovenian Standard Occupational Classification (SKP-V2), which is based on the International Standard Occupational Classification (ISCO-88). Creative core (A) consists of workers who create new knowledge. These are mostly engineers of a technical profile, natural scientists, doctors, teachers, and researchers in the fields of economy, social sciences, and humanities. These highly creative social groups are said to run the social and economic development (SKP-V2 codes: 211-214, 221, 222, 231-235, 243, 244, 247, 344). Creative professionals (B) are made up of experts in labour intense occupations. These are managers, highranking state officials, experts in various technical, educational, medical fields, lawyers, and other occupations that support the social and economic development (SKP-V2 codes: 1, 223, 241, 242, 31, 32, 341-343, 345, 346). Bohemians (C) are creative workers in the narrowest sense of the word. These include musicians, publicists, writers, painters, sculptors, and others (SKP-V2 codes: 245, 347, 521).

The differences in residential concentration of the creative class between city-regions on the one hand and between urban-rural types on the other hand were calculated by location quotient (LQ). The LQ itself is a measure of spatial concentration, expressed as a proportion such that the average for Slovenia is 1 . The differences in residential concentration of the creative class within city-regions on the one hand and within urban-rural types on the other hand were calculated by locational Gini coefficient (Krugman 1991). It can take values between 0 (even distribution across settlements) and 1 (extreme concentration in one settlement). Finally, the dataset for the creative class location quotient (LQ) was constructed for every settlement. Based on it statistical differences between city-regions on the one hand and between urban-rural types on the other hand were examined by the Kruskal-Wallis test which is a non-parametric counterpart of the one-way independent ANOVA (Field 2009).

\section{Spatial distribution of creative-knowledge economy in Slovenia}

Slovenia as a country and Ljubljana as its capital and a middle-sized city can compete with their comparable European counterparts in terms of concentration of the creative class, i.e. in Slovenia being around one third of the workforce. Previous analyses have shown that creative economy is a growing sector in the post-socialist context, similarly to tendencies observed in Western Europe (Kozina and Bole 2017a; 2017b). Creativity as such is strengthening its societal position, which is manifested in the spatial expansion and dispersion of the creative class. The background for such spatial development in Slovenia and Ljubljana can be found in the post-independence European-style culture- and creativity-driven urban policy that was introduced into Slovenian development policies as well as in concrete spatial projects that are visible in Ljubljana in particular and the further shifting of attention towards Ljubljana as the main creative and innovative centre of Slovenia (Ehrlich, Kriszan and Lang 2012; Poljak Istenič 2015; 2016). In the following section we present the results of the empirical analysis to answer the question what matters more in understanding the residential location of the creative class: city-region or urban-rural framework? 


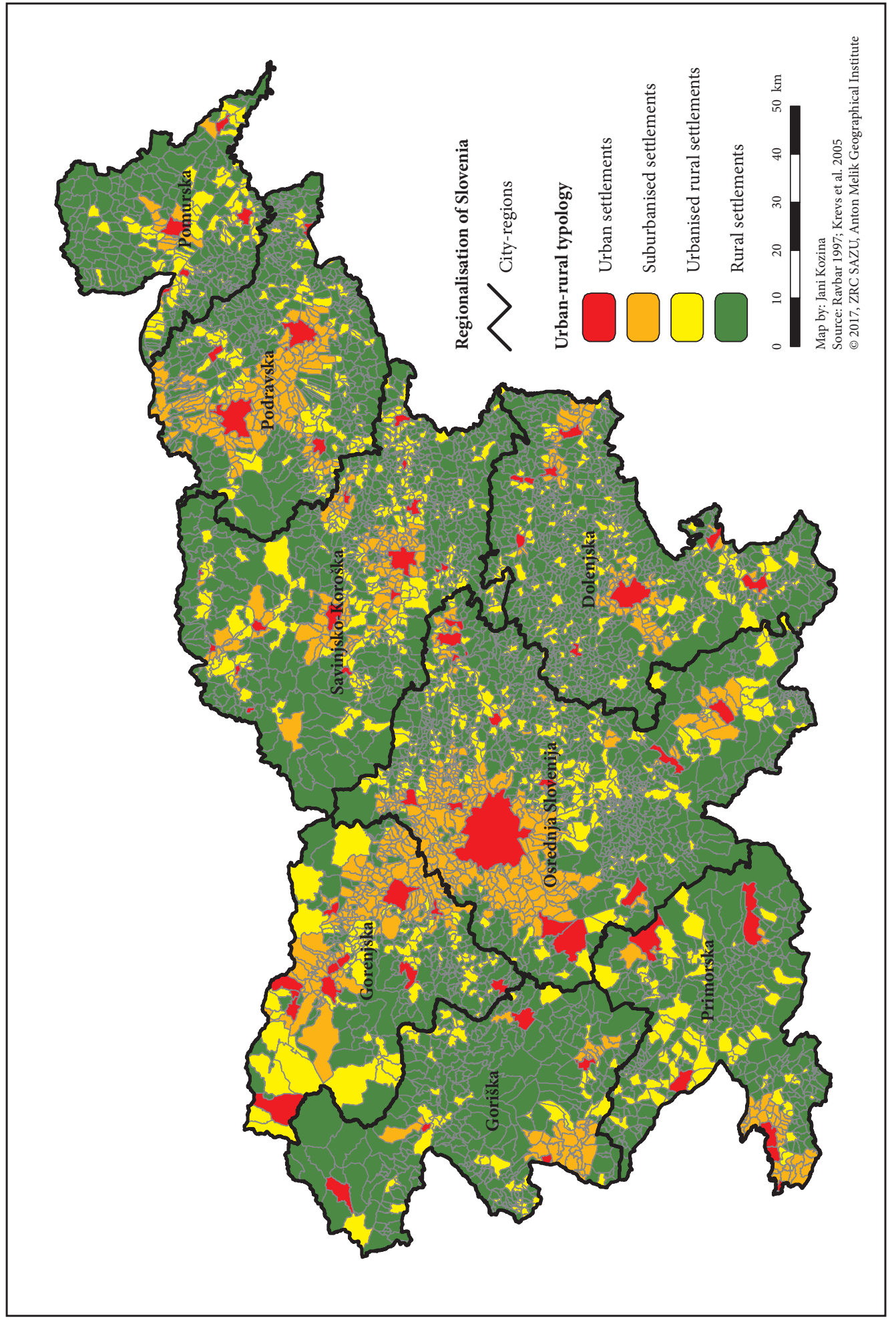




\subsection{City-regional differences}

Slovenia can be divided into three relatively homogeneous areas according to the residential distribution of the creative class (Figure 1). The first is the area of eastern Slovenia (Dolenjska, Savinjsko-Koroška, Podravska, and Pomurska), where the concentration of all three creative sub-groups is below the national average, most notably in the case of the bohemians. Compared to western Slovenia, the east is economically less developed. The second area is Osrednja Slovenija with the capital of Ljubljana as its core city. This is the only region where members of the creative class are highly overrepresented. The third area is denoted by other regions of western Slovenia (Primorska, Goriška, and Gorenjska), where location quotients range around the average.

Between 2000 and 2011, the volume of the creative class increased by $27 \%$ in Slovenia. During the same period, the labour force in manufacturing shrank by $30 \%$, while the number of workers in services $(+1 \%)$ and agriculture $(-2 \%)$ stagnated. Sectoral changes in the economic base clearly signify the transition to the "creative-knowledge society", mostly on the account of deindustrialization. From the regional perspective, the increase was the largest in Dolenjska (37\%) and the two economically most developed regions: Primorska (33\%) and Osrednja Slovenija (31\%). On the contrary, the increase was the smallest in Pomurska (15\%) as economically the most deprived region.

According to Gini coefficients, the creative class $(G=0.836)$ in Slovenian settlements reflects higher concentrations than the working population generally $(\mathrm{G}=0.773)$ and the total population $(\mathrm{G}=0.760)$. Among city-regions, the residential concentration is the highest in Osrednja Slovenija, Primorska, and Podravska, where the largest university centres are located (Ljubljana, Maribor, and Koper). Between 2000 and 2011, the spatial distribution of the creative class in all city-regions dispersed and became more even. This process has been stronger in the city-regions of eastern Slovenia (Dolenjska, Savinjsko-Koroška, Podravska, and Pomurska) than in the city-regions of western Slovenia (Primorska, Goriška, Gorenjska, and Osrednja Slovenija) (Table 1). The reasons for this may be twofold. The first reason could be prescribed to economically more developed urban centres of western Slovenia that attract the creative class to a greater extent than economically less developed urban centres of eastern Slovenia. The second reason could be identified in settlement structure which is in western Slovenia generally denser and more compact than in eastern Slovenia.

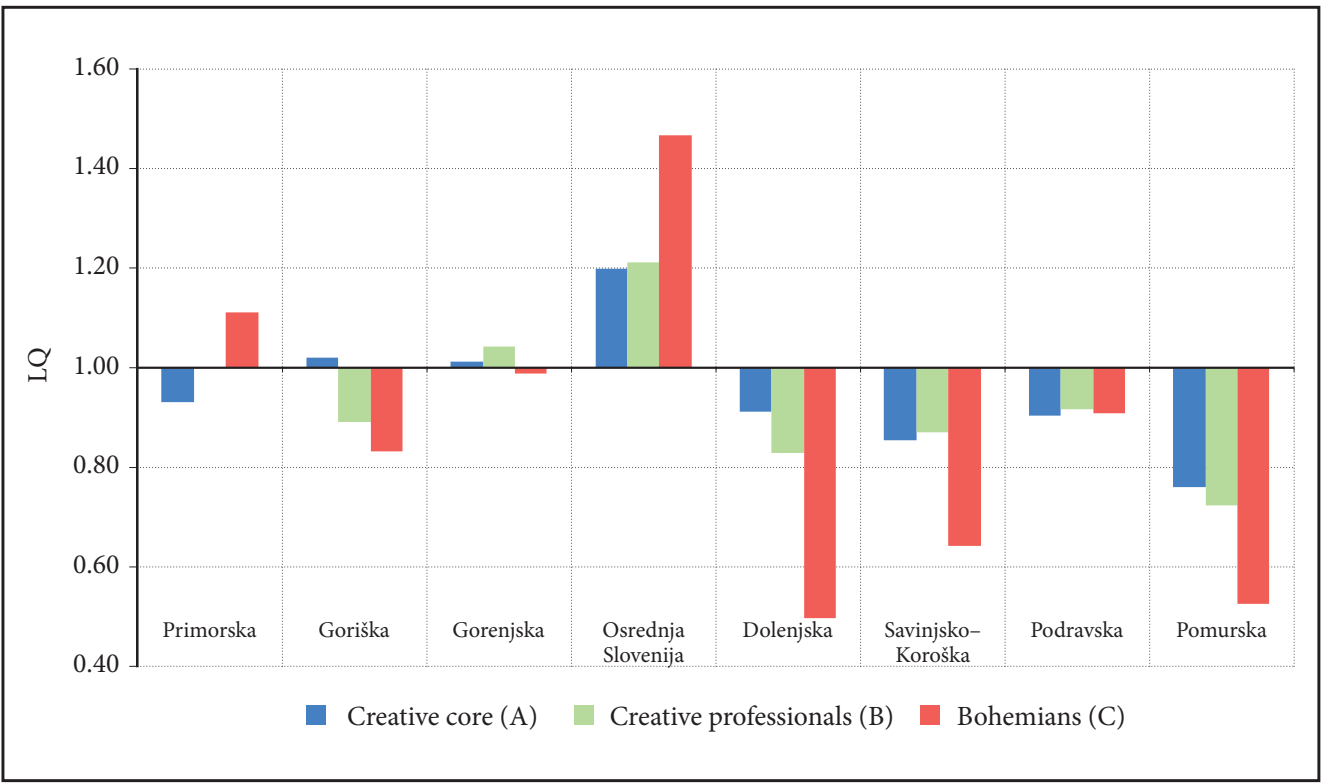

Figure 2: Spatial distribution of the creative class in city-regions of Slovenia in 2011 (own calculations from the Statistical Register of Employment database). 
In order to verify whether there are statistically significant differences in the settlement concentration of the creative class between city-regions, we used the Kruskal-Wallis test. The results showed that residential concentrations of the creative class $(H(7)=371.4, p<.001)$, creative core $(H(7)=163.0, p<.001)$, creative professionals $(H(7)=267.4, p<.001)$, and bohemians $(H(7)=164.6, p<.001)$ statistically significantly vary between city-regions. In order to gain insight into the differences between exact city-regions, the post hoc testing by using the Mann-Whitney test and Bonferroni correction was applied. In this case, the significance was accepted at a .008 level (for detailed instructions see Field 2009, 565 and 566). The results are summarized and illustrated in the error bar charts, where the red arrows connect city-regions with no statistically significant differences in residential concentration of the creative class and its subgroups (Figure 3).

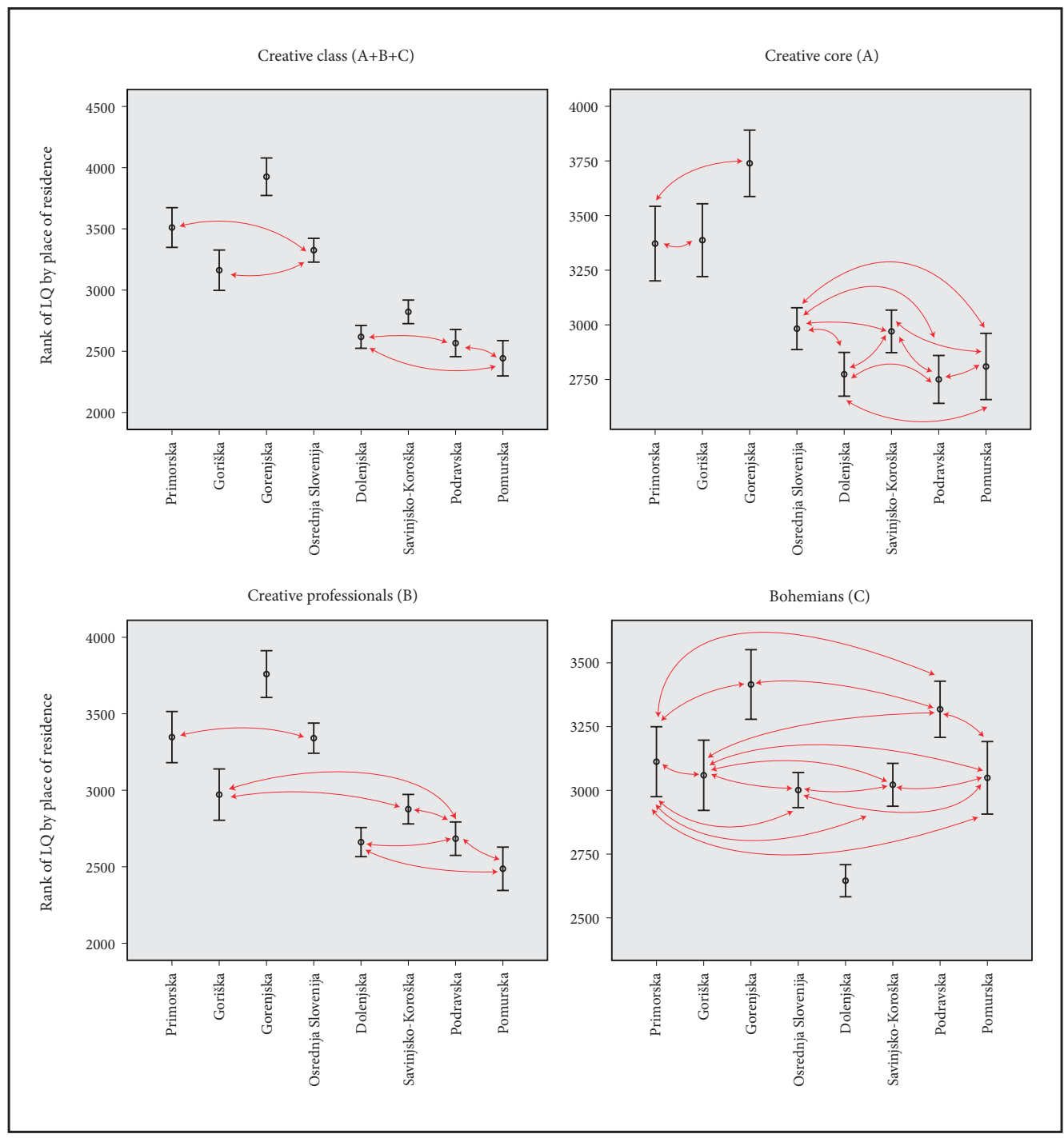

Figure 3: The results of post hoc testing by using the Mann-Whitney test and Bonferroni correction. Error bar charts present the spatial distribution of the creative class across city-regions in Slovenia. The red arrows connect city-regions with no statistically significant differences in residential concentrations of the creative class (own calculations from the Statistical Register of Employment database). 


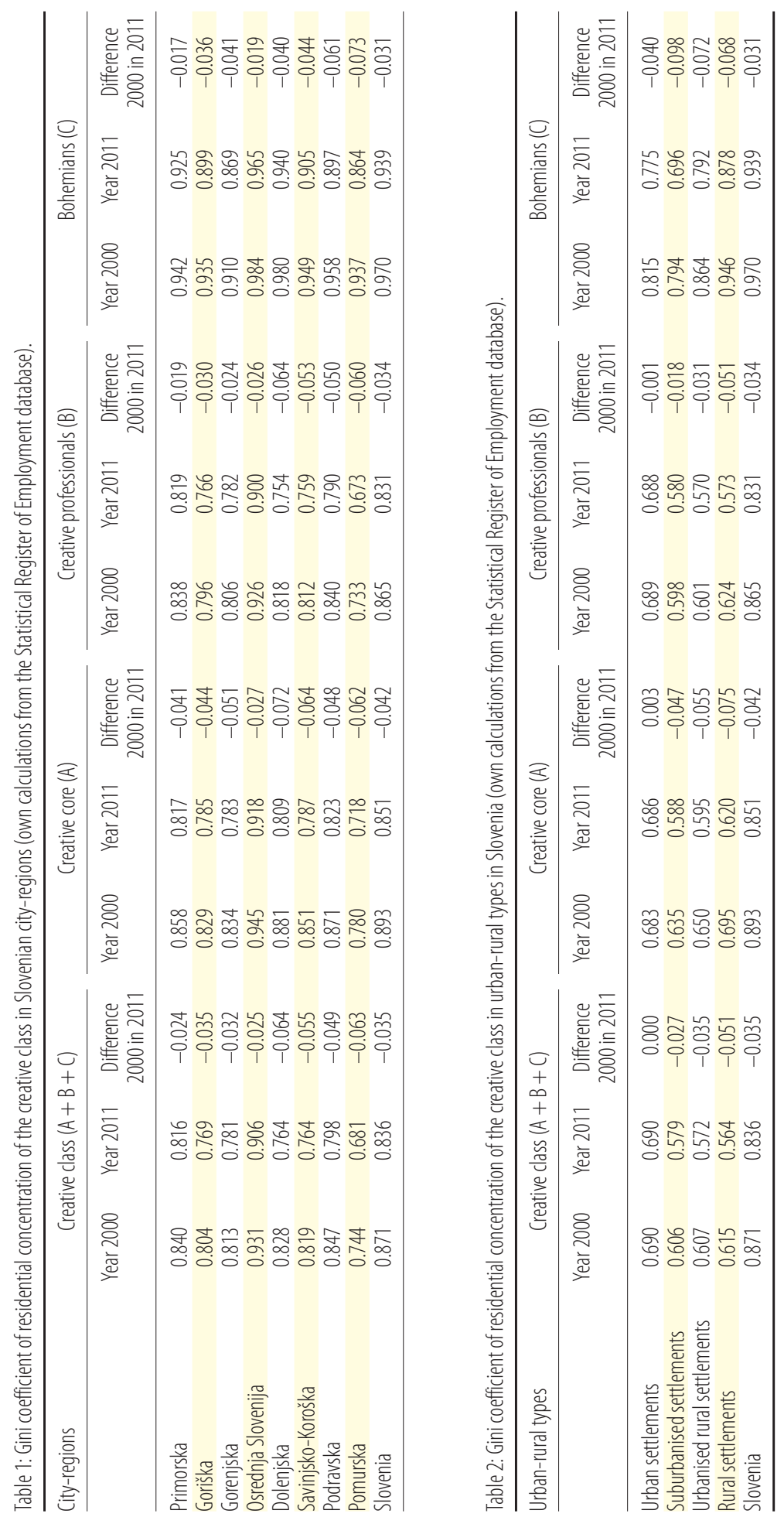


Again, we can see a sharp division between the area of eastern Slovenia (Dolenjska, Savinjsko-Koroška, Podravska, and Pomurska) and the area of central and western Slovenia (Osrednja Slovenija, Primorska, Goriška, and Gorenjska) at an aggregate level of the creative class. A divide is more significant when we compare spatial distribution of the creative core and less notable when it comes to the creative professionals and the bohemians. Especially the last group reflects quite similar proportions of spatial distribution within most of the city-regions in Slovenia.

\subsection{Urban-rural differences}

The spatial distribution of the creative class in Slovenia is highly and positively correlated with the degree of urbanisation; i.e. members of the creative class predominantly reside in urban settlements. The differences are the biggest in case of the bohemians and the smallest in case of the creative professionals. The latter, however, are also overrepresented in suburbanised settlements (Figure 4).

Between 2000 and 2011, the volume of the creative class increased in all types of urbanisation. However, the increase was the smallest in urban settlements (15\%), moderate in suburbanised and urbanised rural settlements (41\%, respectively), and the biggest in rural settlements (67\%). The urban settlements have grown above the average in most of central and western Slovenia (Osrednja Slovenija, Primorska, and Gorenjska) and Dolenjska. In Goriška and most of eastern Slovenia (Savinjsko-Koroška and Podravska) the increase was recorded as below average, while it was in Pomurska even negative. Suburbanised settlements have grown above the average only in Osrednja Slovenija and Primorska. Both types of rural settlements have increased the most in Osrednja Slovenija and Dolenjska, and moderately in Primorska and Podravska. In other city-regions, these two types have shrunk.

According to Gini coefficients, the residential concentration of the creative class is the highest in urban settlements and lower in other types of urbanisation. However, between 2000 and 2011, the ratio between urban settlements has not changed much, while the other types recorded dispersion (Table 2). In other words, all aspects of the creative class are becoming more evenly distributed within all types of area, other than urban.

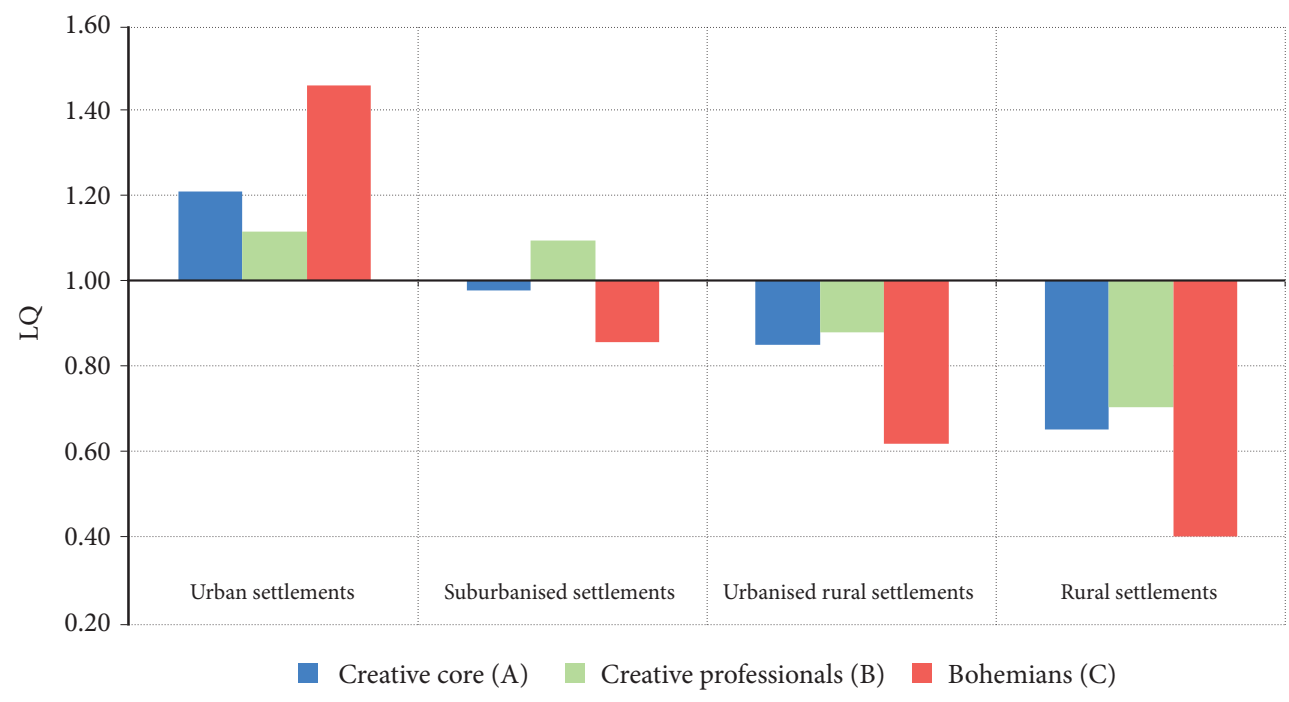

Figure 4: Spatial distribution of the creative class in different types of urbanisation in Slovenia in 2011 (own calculations from the Statistical Register of Employment database). 
In order to verify whether there are statistically significant differences in the settlement concentration of the creative class between urban-rural types, we used the Kruskal-Wallis test. The results showed that residential concentrations of the creative class $(H(3)=47.8, p<.001)$, creative core $(H(3)=62.4, p<.001)$, creative professionals $(H(3)=40.4, p<.001)$, and bohemians $(H(7)=30.1, p<.001)$ statistically significantly vary also between urban-rural types. In order to gain insight into the differences between exact urbanrural types, the post hoc testing by using the Mann-Whitney test and Bonferroni correction was applied. In this case, the significance was accepted at a .002 level (for detailed instructions see Field 2009, 565 and 566). The results are summarized and illustrated in the error bar charts, where the red arrows connect urbanrural types with no statistically significant differences in residential concentration of the creative class and its subgroups (Figure 5).

Here, we can see a sharp division between most of the urban-rural types. The only exception is a similarity between urban and suburbanised type, mainly on the account of creative professionals.
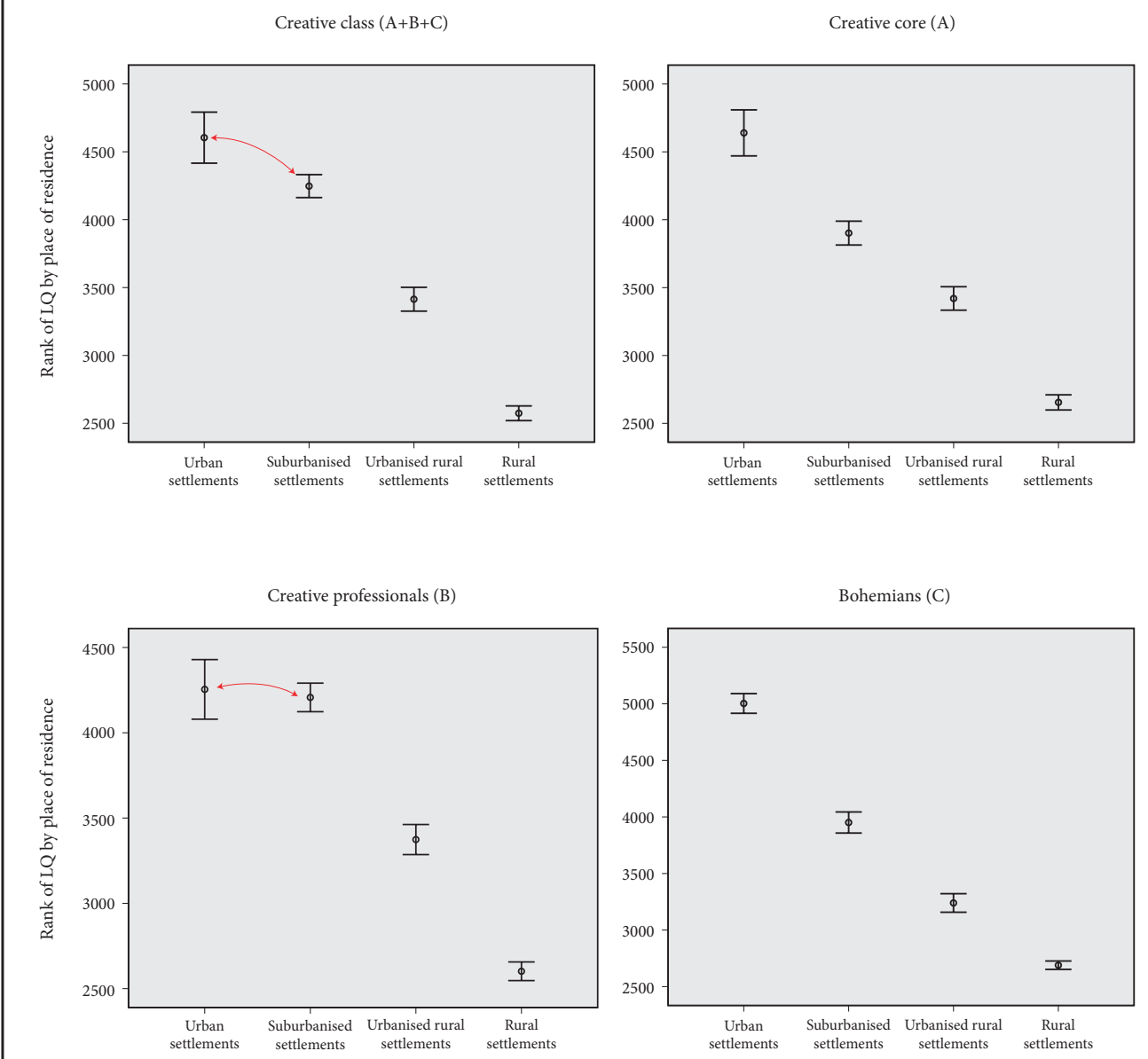

Figure 5: The results of post hoc testing by using the Mann-Whitney test and Bonferroni correction. Error bar charts present spatial distribution of the creative class across urban-rural types in Slovenia. The red arrows connect urban-rural types with no statistically significant differences in residential concentration of the creative class (own calculations from the Statistical Register of Employment database). 


\section{Discussion}

The key question addressed by this paper is what matters more in understanding the location of the creative class: city-region or urban-rural framework? By analysing microdata from the Statistical Register of Employment by the Statistical Office of the Republic of Slovenia we tested the hypothesis that differences in residential concentration of the creative class between urban and rural areas are bigger than between city-regions.

We found that members of the creative class in Slovenia predominantly reside in urban areas. A further analysis confirmed the findings of Markusen (2006) and Bontje and Kepsu (2013) about the higher attraction of urban areas for all of the creative subgroups, while the creative professionals are also more attracted to suburbanised areas. As expected, these findings suggest that creative-knowledge activities are predominantly urban-centric phenomenon.

More significantly, a temporal analysis exposed a dispersion of residencies of the creative class as the main spatial trends in the period 2000-2011. When deciding where to live, the creative class is moving out of densely populated urban areas to more sparsely populated suburban and rural areas within all Slovenian city-regions. The average change in locational Gini coefficient in the investigated period was -0.035 . These trends are generally in line with the spatial processes in other city-regions (Parr 2005). As claimed by Ravbar $(2002 ; 2011)$, this would suggest that the urban system is gradually transforming from a hierarchical structure of settlements to a more balanced network of nodes. It is based on modern principles of weak hierarchical relations and dispersed development poles at infrastructural nodes. According to him, changes in the socioeconomic structure of the population, associated with the rise in living standards, decisively motivate people when deciding on where to live. New living conditions promote dispersion encompassing processes such as suburbanisation, peri-urbanisation, and counter-urbanisation.

However, in comparison to other occupational groups and the total population the observed residential de-concentration of the creative class is stronger. Subsequently, we may contest the claim that the creativeknowledge economy is fundamentally a predominantly urban-centric phenomenon. In the long run, it appears to be gaining a mixture of rurality and suburbanity. As reported by some authors, attraction to rural areas might be attributed to quality of life, access to outdoor amenities and activities, the quality of local schools, and social and cultural interaction (McGranahan and Wojan 2007; White 2010). For those moving from urban to rural areas, the attraction factors are usually not related to employment opportunities. However, many newcomers are torn between »city-businesses« oriented towards the city market and »local business « oriented towards customers in their local area. In order to avoid long commuting time to the city and to continue creative career in sectors new to the rural areas, they adapt their business to a wider regional context (Herslund 2012).

At this point, several questions arise. What is happening with the Slovenian urban system? Why are urban areas becoming (relatively) less attractive to live in? Why do some cities shrink? Conversely, what is happening within the Slovenian countryside that attracts new creative capital? From our spatial analyses, we can conclude that cities in more developed western Slovenia are more attractive to live in than cities in less developed eastern Slovenia. However, the statistical tests (see Figures 3 and 5) showed that significance is stronger when comparing urban vs. rural than when comparing city-regions per se. By taking a closer look at the city-regions it seems that there are significant differences between western and eastern Slovenia (NUTS 2 level). Interestingly, NUTS 2 level serves as a basis to allocate European funding (Cohesion fund, European regional development fund, European social fund). Eastern Slovenia as less developed (GDP is significantly below the average of EU) and is thus eligible to receive higher funding than more developed western Slovenia (some parts of western Slovenia are above the average of EU). Future research should focus on explaining these differences. In addition, more attention should be put on critical evaluation of urban development and revitalisation strategies. As indicated by our results, they have not done their work adequately so far.

The statistical analysis confirmed the hypothesis that differences in residential concentration of the creative class between urban and rural areas are bigger than between city-regions. It could be hypothesised that the creative class in urban areas reflects different residential preferences than the creative class in rural areas. Herein, we agree with Gülümser, Baycan-Levent and Nijkamp (2010) that in terms of abilities and capabilities, urban and rural areas are quite different and that comparing "apples « and "pears" with the same parameters can cause problems. Following from these finding, Regional Development 
Programmes, that try to address regional development in Slovenia, should put more focus into distinguishing between the supply of and demand for urban, suburbanized, urbanized rural, and rural areas. The fact is that different contextual localities request different approaches and methodologies which bring different outcomes.

From the methodological limitations standpoint, our research should be upgraded in the future by a more distinctive urban-rural typology. We agree with Parr (2005) that juxtaposing of the aggregate categories of urban and rural is of very limited value without the introduction of a more specific spatial context. This is because there is such a wide variation within each category. An urban centre of say 250,000 population is inherently different from one of 2.5 million population, while a remote rural area is not to be compared with a rural area in the immediate vicinity of a major metropolitan area. By virtue of this variability, any generalization of urban-rural relations is beset with difficulties (Parr 2005).

Furthermore, the paper only partly addresses the call of Harvey (1985) and Jonas and Ward (2007) to explore the city-region as both a living and as a working place. To this end, analysis by place of work (i.e. as opposed to residence) would be a valuable next research step - particularly with this data also revealing industry of employment; as we know from previous research (e.g. Clifton 2008) occupation is a useful but imperfect capturing of economic activity, which could usefully be augmented by sector data at the individual level as per the "creative trident « approach of Higgs and Cunningham (2008). While it is easy to argue that for city-regions place of residence and place of work are effectively the same thing (city-regions being more or less functional labour markets) this argumentation is less clear when looking at degree of urbanisation - i.e. it is perfectly conceivable to live in a rural area (and certainly a suburban one) while working in an urban one. However, this data is presently not available at the micro level, at least from secondary sources.

In our view, future research should not be limited only to residential locations but correspondingly take into account a deeper investigation of basic human activities such as housing and environment as well as educational, health, supply and social services, and employment opportunities. As claimed by Collinge and Musterd (2009), a holistic approach is indispensable in an effort to attract or retain creative-knowledge workers to certain areas.

Although space constraints preclude it here, our findings suggest that an interesting exercise could be to undertake a "cross-sectional « analysis of the two frameworks employed and look at urban-rural distribution within city-regions; this could potentially reveal intraregional disparities and help add insight to what is happening within city-regions.

From the findings presented here we can also conclude that it would be a useful exercise to undertake similar city-region vs. urbanisation analyses in other European contexts, not least ones in which the urban hierarchy is different (Clifton, Cooke and Hansen 2013). With a larger cross-national sample of city-regions other controls could be introduced into the analysis, regional dummies for example to deal with spatially uneven development. More generally with regional policy-making moving towards a city-region agenda (as per the recent »city deals « in the UK) it is imperative that these dynamics are better understood.

\section{Conclusion}

In this paper we sought to analyse what matters more in understanding the residential location of the creative class in Slovenia: city-region or urban-rural framework. Our analysis revealed that differences in residential concentrations of the creative class vary more within city-regions (on an urban-rural framework) than between city-regions. Although members of the creative class predominantly reside in urban areas, they are moving out of densely populated urban areas to more sparsely populated suburban / rural areas within all city-regions. There are also significant differences found between more developed western Slovenia (denser settlement structures) and less developed eastern Slovenia (sparser settlement structures). We conclude that new models of living are promoting dispersion. Subsequently, we may contest the claim that creative-knowledge activities are fundamentally a predominantly urban-centric phenomenon. In the long run, it appears to be gaining a mixture of rurality and suburbanity.

ACKNOWLEDGEMENT: This work was supported by the Slovenian Research Agency (ARRS) under the programme Geography of Slovenia (P6-0101). The authors are grateful for the insightful comments provided by five anonymous reviewers that significantly improved the paper. 


\section{References}

Andersen, K. V., Hansen, H. K., Isaksen, A., Raunio, M. 2010: Nordic city regions in the creative class debate putting the creative class thesis to a test. Industry and Innovation 17-2. DOI: https://doi.org/10.1080/ 13662711003633496

Bakhshi, H., Davies, J., Freeman, A., Higgs, P. 2015: The geography of the UK's creative and high-tech economies. Report. London.

Bole, D. 2004: Daily mobility of workers in Slovenia. Acta Geographica Slovenica 44-1. DOI: https://doi.org/ 10.3986/AGS44102

Bole, D. 2011: Changes in employee commuting: A comparative analysis of employee commuting to major Slovenian employment centers from 2000 to 2009. Acta Geographica Slovenica 51-1. DOI: https://doi.org/ 10.3986/AGS51104

Bontje, M., Kepsu, K. 2013: Creative knowledge strategies for polycentric city-regions. Place-making and policies for competitive cities. Oxford.

Bontje, M., Musterd, S., Kovács, Z., Murie, A. 2011: Pathways toward European creative-knowledge cityRegions. Urban Geography 32-1. DOI: https://doi.org/10.2747/0272-3638.32.1.80

Bontje, M., Musterd, S., Pelzer, P. 2011: Inventive city-regions: Path dependence and creative knowledge strategies. Farnham.

Boschma, R. A., Fritsch, M. 2009: Creative class and regional growth: empirical evidence from seven European countries. Economic Geography 85-4. DOI: https://doi.org/10.1111/j.1944-8287.2009.01048.x

Bristow, G. 2010: Resilient regions: replaceing regional competitiveness. Cambridge Journal of Regions, Economy and Society 3-1. DOI: https://doi:10.1093/cjres/rsp030

Clifton, N. 2008: The »Creative Class« in the UK: An initial analysis. Geografiska Annaler: Series B, Human Geography 90-1. DOI: https://doi.org/10.1111/j.1468-0467.2008.00276.x

Clifton, N., Cooke, P., Hansen, H. K. 2013: Towards a reconciliation of the »Context-less « with the »Spaceless «? The creative class across varieties of capitalism - new evidence from Sweden and the UK. Regional Studies 47-2. DOI https://doi.org/10.1080/00343404.2012.665991

Collinge, C., Musterd, S. 2009: Deepening social divisions and the discourse of knowledge and creativity across the cities of Europe. Built Environment 35-2. DOI: https://doi.org/10.2148/benv.35.2.281

Davoudi, S. 2003: EUROPEAN BRIEFING: Polycentricity in European spatial planning: From an analytical tool to a normative agenda. European Planning Studies 11-8. DOI: https://doi.org/10.1080/ 0965431032000146169

Davoudi, S. 2008: Conceptions of the city-region: A critical review. Urban Design and Planning 161-2. DOI: https://doi.org/10.1680/udap.2008.161.2.51

Davoudi, S., Stead, D. 2002: Urban-Rural Relationships: An introduction and brief history. Built Environment 28-4. DOI: https://doi.org/10.2307/23287748

Dickinson, R. E. 1947: City Region and Regionalism. London.

Egedy, T., Kovács, Z., Kondor, A. C. 2016: Metropolitan region building and territorial development in Budapest: The role of national policies. International Planning Studies 22-1. DOI: https://doi.org/10.1080/13563475.2016.1219652

Ehrlich, K., Kriszan, A., Lang, T. 2012: Urban development in Central and Eastern Europe - Between peripheralization and centralization? The Planning Review 48-2. DOI: https://doi.org/10.1080/ 02513625.2012.721611

Etherington, D., Jones, M. 2009: City-Regions: New geographies of uneven development and inequality. Regional Studies 43-2. DOI: https://doi.org/10.1080/00343400801968353

Field, A. 2009: Discovering statistics using SPSS (and sex and drugs and rock'n'roll). London.

Florida, R. 2002: The rise of the creative class: And how it's transforming work, leisure, community and everyday life. New York.

Florida, R. 2005: The flight of the creative class: the new global competition for talent. New York.

Florida, R. 2008: Who's your city? How the creative economy is making where you live the most important decision of your life. New York.

Fritsch, M., Stützer, M. 2007: Die Geographie der Kreativen Klasse in Deutschland. Raumforschung und Raumordnung 65-1. DOI: https://doi.org/10.1007/BF03183820 
Geddes, P. 1915: Cities in evolution: An introduction to the town planning movement and to the study of civics. London.

Gülümser, A. A., Baycan-Levent, T., Nijkamp, P. 2010: Measuring regional creative capacity: A literature review for rural-specific approaches. European Planning Studies 18-4. DOI: https://doi.org/10.1080/ 09654311003593614

Hall, P., Tewdwr-Jones, M. 2011: Urban and regional planning. London.

Harrison, J. 2007: From competitive regions to competitive city-regions: A new orthodoxy, but some old mistakes. Journal of Economic Geography 7-3. DOI: https://doi.org/10.1093/jeg/lbm005

Harrison, J., Heley, J. 2015: Governing beyond the metropolis: Placing the rural in city-region development. Urban Studies 52-6. DOI: https://doi.org/10.1177/0042098014532853

Harvey, D. 1985: The urbanisation of capital. Baltimore.

Healey, P. 2009: City regions and place development. Regional Studies 43-6. DOI: https://doi.org/10.1080/ 00343400701861336

Herslund, L. 2012: The rural creative class: Counterurbanisation and entrepreneurship in the Danish countryside. Sociologia Ruralis 52-2. DOI: https://doi.org/10.1111/j.1467-9523.2011.00560.x

Higgs, P., Cunningham, S. 2008: Creative industries mapping: Where have we come from and where are we going? Creative Industries Journal 1-1. DOI: https://doi.org/10.1386/cij.1.1.7/1

Huggins, R., Clifton, N. 2011: Competitiveness, creativity, and place-based development. Environment and Planning A 43-6. DOI: https://doi.org/10.1068/a43559

Jonas, A., Ward, K. 2007: Introduction to a debate on city-regions: New geographies of governance, democracy and social reproduction. International Journal of Urban and Regional Research 31-1. DOI: https://doi.org/10.1111/j.1468-2427.2007.00711.x

Kozina, J. 2010: Transport accessibility to regional centres in Slovenia. Acta Geographica Slovenica 50-2. DOI: https://doi.org/10.3986/AGS50203

Kozina, J., Bole, D. 2017a: Agglomeration of Bohemians across different spatial scales in Slovenia. The impact of artists on contemporary urban development in Europe. Cham. DOI: https://doi.org/10.1007/9783-319-53217-2_8

Kozina, J., Bole, D. 2017b: Creativity at the European periphery: Spatial distribution and developmental implications in the Ljubljana Region. Creative industries in Europe: Drivers of new sectoral and spatial dynamics. Cham. DOI: https://doi.org/10.1007/978-3-319-56497-5_11

Krevs, M., Repe, B., Cigale, D., Grilc, A., Herakovič, A. 2005: Ciljni raziskovalni program (CRP) »Konkurenčnost Slovenije 2001-2006«. Regionalna primerjava spreminjanja poselitve rabe zemljišč med statističnimi regijami v Sloveniji v obdobju 1991-2002: po vzorčnih mestnih in suburbanih območjih. Ljubljana.

Krugman P. 1991: Geography and trade. Cambridge.

Madanipour, A. 2011: Knowledge economy and the city: Spaces of knowledge. New York.

Markusen, A. 2006: Urban development and the politics of a creative class: Evidence from a study of artists. Environment and Planning A 38-10. DOI: https://doi.org/10.1068/a38179

Marlet, G., van Woerkens, C. 2007: The Dutch creative class and how it fosters urban employment growth. Urban Studies 44-13. DOI: https://doi.org/10.1080/00420980701558434

McGranahan, D.,Wojan, T. 2007: Recasting the Creative class to examine growth processes in rural and urban counties. Regional Studies 41-2. DOI: https://doi.org/10.1080/00343400600928285

McKenzie, R. D. 1933: The metropolitan community. New York.

Musterd, S., Gritsai, O. 2012: The creative knowledge city in Europe: Structural conditions and urban policy strategies for competitive cities. European Urban and Regional Studies 20-3. DOI: https://doi.org/ $10.1177 / 0969776412439199$

Pareja-Eastaway, M., Pradel i Miquel, M. 2015: Towards the creative and knowledge economies: Analysing diverse pathways in Spanish cities. European Planning Studies 23-12. DOI: https://doi.org/10.1080/ 09654313.2014.988018

Parr, J. B. 2005: Perspectives on the city-region. Regional Studies 39-5. DOI: https://doi.org/10.1080/ 00343400500151798

Parr, J. B. 2008: Cities and regions: Problems and potentials. Environment and Planning A 40-12. DOI: https://doi.org/10.1068/a40217

Pemberton, S., Shaw, D. 2012: New forms of sub-regional governance and implications for rural areas: Evidence from England. Planning Practice \& Research 27-4. DOI: https://doi.org/10.1080/02697459.2012.682476 
Plut, D. 1999: Regionalizacija Slovenije po sonaravnih kriterijih. Geografski vestnik 71.

Poljak Istenič, S. 2015: Kolo kot akter ustvarjalne urbane regeneracije. Glasnik Slovenskega etnološkega društva 55-3/4.

Poljak Istenič, S. 2016: Reviving public spaces through cycling and gardening: Ljubljana - European green capital 2016. Etnološka tribina: godišnjak Hrvatskog etnološkog društva 46-39. DOI: https://doi.org/ 10.15378/1848-9540.2016.39.06

Ravbar, M. 1997: Slovene cities and suburbs in transformation. Acta Geographica 37.

Ravbar, M. 2002: Sodobne težnje v razvoju prebivalstva in delovnih mest - pot k sonaravnemu in decentraliziranemu usmerjanju poselitve v Sloveniji? IB revija 36-1.

Ravbar, M. 2009: Economic geographical assessment of investments - A development factor in regional development. Acta Geographica Slovenica 49-1. DOI: https://doi.org/10.3986/AGS49105

Ravbar, M. 2011: Creative social groups in Slovenia: Contribution to geographic studying of human resources. Acta Geographica Slovenica 51-2. DOI: https://doi.org/10.3986/10.3986/AGS51204

Rodríguez-Pose, A. 2008: The Rise of the "city-region « concept and its development policy implications. European Planning Studies 16-8. DOI: https://doi.org/10.1080/09654310802315567

Roy, A. 2009: The 21st-Century metropolis: New geographies of theory. Regional Studies 43-6. DOI: https://doi.org/10.1080/00343400701809665

Rutten, R., Gelissen, J. 2008: Technology, talent, diversity and the wealth of European regions. European Planning Studies 16-7. DOI: https://doi.org/10.1080/09654310802163785

Scott, A., Storper, M. 2003: Regions, globalization, development. Regional Studies 37-6-7. DOI: https://doi.org/10.1080/0034340032000108697a

Storper, M. 1997: The Regional World: Territorial development in a global economy. London.

Storper, M. 2013: Keys to the city: How economics, institutions, social interaction, and politics shape development. Princeton.

Tiran, J. 2011: Settlement area type as a factor in electoral behaviour in Slovenia. Hrvatski glasnik 73-1.

Tiran, J. 2015: Urbano proti ruralnemu: (nov) razcep v slovenskem političnem prostoru? Teorija in praksa $52-1 / 2$.

Verdich, M. 2010: Creative migration? The attraction and retention of the "creative class « in Launceston, Tasmania. Australian Geographer 41-1. DOI: https://doi.org/10.1080/00049180903535642

Vintar Mally, K. 2018: Regional differences in Slovenia from the viewpoint of achieving Europe's sustainable development. Acta Geographica Slovenica 58-2. DOI: https://doi.org/10.3986/AGS.3309

Ward, N. 2006: Rural development and the economies of rural areas. A new rural agenda. London.

White, P. 2010: Creative industries in a rural region: Creative West: The creative sector in the Western region of Ireland. Creative Industries Journal 3-1. DOI: https://doi.org/10.1386/cij.3.1.79_1

Woods, M. 2009: Rural geography: Blurring boundaries and making connections. Progress in Human Geography 33-6. DOI: https://doi.org/10.1177/0309132508105001 